\title{
Transgressions and Reterritorializations as Markers of Minor Literature in Kurt Vonnegut's Slapstick, or Lonesome no More!
}

Meryem Mengouchi and Wassila Hamza Reguig Mouro

https://doi.org/10.30608/HJEAS/2021/27/2/12

\begin{abstract}
Deterritorialization and reterritorialization are transgressive techniques in literature that characterize subversive literature. Gilles Deleuze and Félix Guattari suggest that questions about marginal literature or other forms of peripheral literatures must all be covered within the designation and definition of minor literature, not only if they are written in the language of the mainstream. Kurt Vonnegut's Slapstick, or Lonesome no More (1976) is a set of deterritorializations and reterritorializations made possible through creative assemblage, a technique that allows a continuous flow of meaning, that is, meaning is not fixed, as language moves from one territory to another, constructing new assemblages and acquiring new meanings. Meaning changes each time a new assemblage is composed. Through the reconstruction of family, love, and human relationships, the novel defies the alienating practices of the American society as presented in Vonnegut's novel. (MM and WHRM)
\end{abstract}

KEYWORDS: deterritorialization, reterritorialization, assemblage, trangression, Vonnegut

Slapstick, or Lonesome no More, published in 1976, is Kurt Vonnegut's eighth novel about "desolated cities and spiritual cannibalism and incest and loneliness and lovelessness and death" in the author's words (18). Slapstick stages a future America that lives in total chaos, where young people are hungry, ignorant, and uneducated. The only way for them to obtain food is 
through serving as slaves in the properties of richer people. The novel narrates the story of two siblings who live in total isolation because of their odd physical appearance. Its main concern is loneliness and the suggestion of extended artificial families to overcome it.

This paper claims that Slapstick, or Lonesome no More integrates aspects of minor literature, harking back to the concept introduced by Gilles Deleuze and Félix Guattari in their book Kafka: Toward a Minor Literature (1975) and defined as the product of a "minority within a major language" (16). The two protagonists in Vonnegut's novel, Wilbur Rockefeller and Eliza Mellon Swain, are born with "neanderthaloid" features and show signs of mental illness, which make them different from other people surrounding them (Slapstick 28). The siblings' physical and mental difference is both a torture and a bliss since it is the cause of their rejection by their parents and of their creating a secret and intimate universe for themselves. In that self-produced world, they are highly intelligent, yet they must hide it since they are believed to have no intelligence at all. They invent the idea of the extended artificial family for all Americans, which becomes a general American policy in the country under Wilbur's term as President of the United States.

The act of producing minor literature entails the actions of deterritorialization and assemblage. Language in deterritorialization loses its function of representation, which is its ordinary use, as it begins to create meaning rather than reproduce a previously existing one, yet it recovers this loss by reterritorializing itself. The reappropriation of language in Slapstick is related to the author's status in the society he depicts in his work. He states that the novel is about "loneliness and lovelessness" (18), which he rejects in his society. By regaining the territory in literature in favor of these overwhelming problems, he sheds light on a probable minority that is struggling against these phenomena in silence - a minority that he is part of, one that makes his characters feel disturbed by the social constraints that surround them. Language is deterritorialized from the grand narratives-which reinforce a traditional 
discourse - to a less common and less popular literature, about unfortunate anti-heroes, "incest and loneliness and lovelessness and death" (18).

Wilbur and Eliza build their secret world in intimacy, which is their act of transgression, while their parents as well as doctors think they are too dull-witted to live among human beings. They become displaced; however, from the sick and hopeless young people they are considered to be, they change into geniuses. In their transgression they reappropriate the language of their social group, who think that they do not need to use language and mark their differences. This language reappropriation follows Deleuze and Guattari's model of deterritorialization. When language recognized as the privilege of the majority is reappropriated by the minority, it is deterritorialized to represent new groups and meanings that were denied before (Deleuze and Guattari, Kafka 16-17).

The secret life of Wilbur and Eliza unfolds through a series of assemblages. An assemblage is a collection of multiplicities that are brought together in an act of reterritorialization, thus giving life to an idea or an identity that never existed before (Deleuze and Guattari, A Thousand Plateaus 33). The act of reterritorialization reveals new possibilities of existences and territories, within which minorities can be central, rather than marginal players.

This essay suggests that metafiction as a tool used by Vonnegut to abandon the traditional forms of fiction writing underlines aspects of minor literature, which are incorporated in Slapstick. This novel is not only aware of its artificiality, but it also flows freely from one setting to another by disrupting the linear form of narration. The prologue calls attention to the self-referentiality of its writing process when the author himself introduces Slapstick as an autobiography about himself and his sister (Vonnegut 1).

Transgression in the novel is built on alienation from the commonly acknowledged perception of family-life as Wilbur and Eliza are rejected based on their ugliness and the 
assumption of the deficiency of their mental health. They are estranged from the real world and its logic, which makes Vonnegut's work both subversive and artistic, and places it in the generic category of science fiction. As Darko Suvin states, estrangement "differentiates SF from the 'realistic' literary mainstream" (8) and it essentially characterizes science fiction as a genre. He borrows the term from Bertolt Brecht, who defines it as that which "allows us to recognize [the] subject, but at the same time makes it unfamiliar" (qtd. in Suvin 6). Advancing Brecht's definition, Suvin further elaborates on it and adds: "the effect of . . factual reporting of fictions is one of confronting a set normative system ... with a point of view or look implying a new set of norms, in literary theory this is known as the attitude of estrangement" (6).

Estrangement is based on the aspect of newness, since this quality makes literary representation different as opposed to the realistic one. The "new set of norms" is entangled with the idea of novum, which Suvin defines as a "spectrum or spread of literary subject matter which extends from the ideal extreme of exact recreation of the author's empirical environment to exclusive interest in a strange newness" (4).

Estrangement is closely related to the idea of novum, as a matter of fact, it cannot exist without it. Novum, according to Suvin, is what differentiates science fiction from the "exact recreation of the author's empirical environment," (4) in other words, from realism. Yet, a representation which alienates the reader from the usual, and which presents something new, can easily be confused with fantasy and the supernatural; therefore, Suvin links estrangement to cognition. Thus, science fiction must include the aspect of cognitive estrangement and it is a "literary genre whose necessary and sufficient conditions are the presence and interaction of estrangement and cognition, and whose main formal device is an imaginative framework alternative to the author's empirical environment" (Suvin 7-8).

Estrangement takes Slapstick through a series of transgressions that are both aesthetic and fictional. The first transgression occurs in the textual agency and narrative technique: the 
disruption of the traditional writing system is a transgression in itself, a shift to a more creative, and different, writing tradition to de-center the grand narratives and illuminate new experiences of commonly marginalized groups (Deleuze and Guattari, Kafka 18).

Vonnegut's demolishing grand narratives begins by de-centering the typical mainstream upper class individual and foregrounding simple, not-so-attractive characters like Wilbur and Eliza. They are born in a rich family and their parents are a good-looking young couple (Vonnegut, Slapstick 28), who visit them in a "chauffeur-driven Mercedes limousine" (110). The parents are dismayed by the physical appearance of the twins, whom they consider to be unsightly, and are ashamed of them (27). Wilbur and Eliza look too big for their age, have extra toes, and supernumerary nipples (27). Judged mentally ill, they are thought to be unable to learn to speak; therefore, they are expected by doctors to die before the age of fourteen (28). Appalled by their physical appearance, their parents place them in a renovated mansion away from the city, with a number of servants. They visit them only on their birthday, once a year (30).

The parents represent two attractive, well-mannered rich Americans, who could feature in any grand narrative realist fiction. However, Vonnegut de-centers the idea of the goodlooking hero and chooses characters who live on the margin so their life fails to exemplify Western cultural values. Wilbur and Eliza, forsaken by their parents, develop their own understanding of social behaviors by acting childishly when separated from each other. When placing these atypical protagonists in the center of the novel, Vonnegut shows the other side of American culture, by which he exemplifies the politicization of the affairs of the minority group in Deleuze and Guattari's understanding:

The second characteristic of minor literatures is that everything in them is political. In major literatures, in contrast, the individual concern (familial, marital, and so on) joins with other no less individual concerns, the social milieu serving as a mere environment 
or a background . . . Minor literature is completely different; its cramped space forces each individual intrigue to connect immediately to politics. The individual concern thus becomes all the more necessary, indispensable, magnified, because a whole other story is vibrating within it. In this way, the family triangle connects to other trianglescommercial, economic, bureaucratic, juridical-that determine its values. . . What in great literature goes on down below, constituting a not indispensable cellar of the structure, here takes place in the full light of day. (Kafka 17)

In minor literature, everything that happens in the life of a minority is an important matter, unlike their lives with the majority group, who marginalize them. They are "necessarily political" due to their status as marginal (17). Being in opposition to their environment (family, doctors, servants), Wilbur and Eliza represent a marginalized group. Their central position in the novel underlies the attention and value given to their lives. In Slapstick, just as in minority literature, everything that Wilbur and Eliza do is politicized.

Vonnegut also establishes a direct connection between his work of art and his real world, albeit still emphasizing its artificiality. This projection reveals the author's true intentions and hopes in new and alternate universes of fiction. Language is "an independent, self-contained system which generates its own 'meanings"' (Waugh 3); thus, the dislocation of perception is not only related to the production of new meanings, but also to the suggestion of the emergence of new ones that might, or might not, happen. The first-person narrative voice in the prologue, a metafictional device, encourages the reader to relate the events of the text to the life of the author. Vonnegut states that this novel is the closest he had ever got to writing an autobiography (Slapstick 1).

He recounts his relationship with his brother, Bernard, and his understanding of love; he informs the reader that the main characters, Wilbur and Eliza, represent Vonnegut and his 
dead sister, that his sister was "the person [he] had always written for," and adds that "[s]he was the secret of whatever artistic unity I had ever achieved. She was the secret of my technique $\ldots$ and she was nice enough . . . to allow me to feel her presence for a number of years after she died — to let me go on writing for her" (15-16). He admits that love has never taken a great part of his life, nor has he received much of it. Vonnegut enters again at the end of the novel to finish the story of his speaker, whom he identifies as his future self in the prologue (19). The reader addressed directly is immersed in the narration. The author's interaction with the reader legitimately calls for the author's life for interpretation, since "it is about what life feels like" to Vonnegut himself (1, emphasis in the original).

The novel is a composition of different interrelated plots. The first plot is about Wilbur and Eliza, the "neanderthaloid" children born with malformations and adult features (28). They grow up together as one, in physical and mental oneness. When they touch and bring their heads close to each other, they think as one and become a "single genius" (127). The siblings promise their parents that they "will make this mansion famous for intelligence as it has been infamous for idiocy in days gone by. Let the fences come down" (74). They are led by the excitement of making their parents happy and proud, but also have the chance to celebrate their intelligence in public for the first time. The miraculous talent of the two siblings is due to their isolation from society during their entire childhood. The two children start to share secrets at a young age and are amused by the complicity of playing games on their doctor and servants. Yet, when they "allowed [their] heads to be separated," they were "not thinking brilliantly anymore" (76).

Wilbur and Eliza attempt to recover their peaceful lives by showing their excellence while they are united. Their genius is entirely lost when they are separated and forced to live in a social group. It must be noted, however, that the novel is not a call for isolation and separatism, neither does it claim that human beings are bad. Nevertheless, it shows how individuals change and how much they lose when they are obliged to live according to the norms of society imposed 
on them. The fact that the two protagonists manifest happiness and serenity when they are united is a transgression. They defy a society that devalues their power as created in their intimate world.

In the second plot, Wilbur becomes president of the United States, but the country goes bankrupt. This is a bizarre utopia in which everyone is poor, ignorant, and starving; however, they are happy in their extended families. The group of people discussed in this part of the novel live in isolation due to a virus that has spread on Manhattan Island-referred to as the Island of Death (22). The only program that works in Wilbur's term is the extended artificial familyproject.

Another transgression happens at the level of the language, identified by Deleuze and Guattari as language deterritorialization, which is the reappropriation of the language of the majority by the minority. The use of the language of power by the oppressed subject, even when this language is the mother tongue of the latter, is an act of transgression. The alienation of the subject from power systems proves to be an incentive and a strong factor in the politicization of their experience and writing.

The act of writing itself is also an act of transgression since it goes beyond the boundaries of the real as it transcends the world of the possible to the imaginary (Jenks 2). Imagination is not merely entertainment, but a recreation of meaning and reterritorialization. It marks a shift away from the common grand narratives of power, to adopt a more "nomadic" perspective (Deleuze and Guattari, A Thousand Plateaus 25), allowing for the expression of difference. In the novel, the act of alienation is first discerned in the world of Wilbur and Eliza, who grow up as a minority. Its second appearance is that of the isolation of the Island after the virus is spread in the country: the inhabitants of the island become different from other Americans, and in their separation they become poor, hungry, and uneducated. 
When Wilbur and Eliza develop their own ideas of social values on account of their loneliness, they emphasize their status as minoritarian. In their draft of a new constitution, they endorse the idea of artificial families, which ensures the right of family for each individual, even if they are insane (Slapstick 40). When proposing this, they act like a minority that shares a common experience of marginalization and seeks to express themselves.

By cultivating their own ideas of what social life should be like, they create a new line of differences. They transgress the usual lines of stratification built by society by creating their own definitions of what society wants, as "[a]11 the information we received about the planet we were on indicated that idiots were lovely things to be. So we cultivated idiocy" (31). Vonnegut establishes lines of multiplicity and destratifications that continue to develop through the narrative and subsequent interpretations.

Wilbur and Eliza build their own world in which they reterritorialize their lives into an unconsciously incestuous universe of their own. They replace words with meaningless babblings and roll on the floor making the others believe that they are unaware of the world around them. Before their separation, the siblings construct their own isolated space as a form of defiance of their social environment. They hide in the library where Wilbur reads to Eliza, while she does most of the thinking. They are separated by a psychologist who thinks that Wilbur is the more intelligent of the two because of his ability to read. Eliza, on the other hand, is placed in an institution as she is judged mentally ill.

Language deterritorialization arises when Wilbur and Eliza stop pretending that they are not able to speak or understand fluent English; instead, they start using it to get acceptance from their parents and society. When they reveal their true selves, they perform an act of deterritorializaion and reterritorialization at the same time. They steal the language "from its crib" (Deleuze and Guattari, Kafka 17), to make it their own in an act of deterritorialization, but also enter reterritorialization as this language starts to cover a new area restricted before, that 
is, Wilbur and Eliza's secret life. Wilbur and Eliza find their happiness in their isolation through reterritorializing their comfort. Their secret world is an assemblage, composed of a series of escapes from their assigned prison.

Assemblage is the culmination of lines that flow away from closure and which can belong to any territory at any point in time. Deleuze and Guattari describe assemblage as having no subject, object, nor end; it has no influence and cannot be fixed. When lines of articulation and territories meet, they make an assemblage (A Thousand Plateaus 33). Manuel De Landa describes it as a whole composed of independent entities instead of dependent parts (9). An assemblage is a site at which ideas that are escaping closure meet to compose something new and different which has no precedent (Deleuze and Guattari, A Thousand Plateaus 33).

Wilbur and Eliza's secret world is an assemblage: it is not planned but it occurs as a result of a series of escapes during an attempt at regaining territory. They develop power that only the two of them can experience when they are together, since their brains function as one only when they are close to each other. Thus, their intimacy is a reterritorialization in which they can find comfort and happiness. Their comfort, however, is disrupted as soon as they reveal their true selves to their surroundings.

Vonnegut defamiliarizes the ideas of love and conspiracy through the characters of Wilbur and Eliza. He achieves this by drawing an incestuous relationship between the two siblings, who are entirely innocent: their understanding of life and of human relationships has been obtained from the books they are secretly reading, and is the product of their own silent and shy experimentation with their environment.

At the age of fourteen, Wilbur and Eliza hear their mother wishing they were more intelligent, as she would love them more if they were (69). They decide to surprise their parents hoping to receive their love, and disclose the truth about themselves: they are bright and can speak and think just like any normal human being. The revelation is received with dismay by 
their parents, who decide to turn them over to a number of doctors, including Dr. Cordiner, a psychologist, for an explanation of the phenomenon (86). As Cordiner is convinced that rich children are spoiled, she thinks the two in front of her are no exception (91), therefore she tests Wilbur and Eliza snobbishly, asking tricky questions to trap them. She eventually discovers that Wilbur is able to read and write, while Eliza has never learnt to read, as in their isolated life she is the one to provide ideas (51). Her verdict is that Wilbur is the more intelligent of the two, whereas Eliza has no intellectual abilitites when separated from her brother and thus has to be institutionalized.

Their separation disturbs them greatly. Eliza makes Wilbur promise that he will not leave her, yet, if it happened, they should drop their birth names since these two represent a sacred bond (100). She suggests the names Bobby and Betty Brown as alternatives for the new and completely different people they will become when they are no longer together. Indeed, after her death, Eliza is named Betty Brown on her tombstone (88), while the narrator, Wilbur, often refers to himself as Bobby when he speaks of the period that followed their severance. Bobby and Betty Brown mark the end of the siblings as one genius.

Wilbur and Eliza are two humans raised as intellectually disabled; thus, they never receive any education about human relations. Their separation is devastating, particularly for Eliza, who seeks to meet her brother again by revengeful means because he forgets everything about her. While Wilbur has the chance to be schooled and lead a normal life with his mother, Eliza is entirely abandoned, locked up in "an institution for the feeble-minded" (111). When the two meet again, their reunion comes in the form of an orgy in which they recreate their comfortable territory.

Deterritorialization followed by reterritorialization, through an act of dislocation which then re-situates itself, is a technique to help the protagonists escape from the culture of prejudice and elitism they are victims of. They are transformed into different ways of being at the level 
of form, in which language is altered, as well as at the level of meaning: words start to acquire new meanings, like the word "love," or those connected to the events happening to the main characters, particularly to Wilbur when he becomes president and America goes bankrupt.

In the prologue of Slapstick Vonnegut describes love as "poisonous," as a word that includes exaggerated feelings which need moderation, and argues that relationships must be built on "common decency" instead (3). He thinks that when lovers fight they should tell each other "please - a little less love, and a little more common decency" (3). Common decency is less radical than love, but it requires less engagement and pretence. The dislocation of lovean aestheticization of the author's life experience into "grotesque situational poetry"-is affected by Vonnegut's limited experience with it, as he admits having had very little love in his life (2). Through this displacement and metafiction, Vonnegut creates a direct link between his life and the novel, and illustrates the fictionalization of the real world.

The question of love is raised between Wilbur and Eliza as well. Wilbur wishes to tell Eliza that he loves her because he has read that human beings express attachment to each other using the expression "I love you" and that it is "the most important thing of all" (108). Wilbur believes it is of great relevance since he has no knowledge of human relationships or what they should be like. Eliza, however, rejects Wilbur's expression of love and views it as "pointing a gun" at somebody's head, which compels the person to say "something they probably don't mean" (108). She thinks that the widely accepted definition of love carries much obligation and engagement that the persons involved have to manifest. Eliza and Wilbur express their love differently through their complicity and intimacy in isolation, which matches Vonnegut's view of love as being overrated.

An important act of transgression is achieved by Wilbur, who turns his ideas about the extended family — once his and Eliza's shared theory developed to overcome loneliness — into a successful national project when he becomes President of the United States. He assigns all 
American citizens artificial names and numbers which connect them as family members when the names match, thus creating what he calls the extended artificial family. His goal is to provide care and company to every American wherever they go. Slapstick at this point becomes the description of the state machine of a world yet-to-come. It is a machine that deterritorializes, then reterritorializes meaning into worlds which marginal groups, through acts of transgression, can identify with.

Since Wilbur and Eliza think the American Constitution empowers only the wealthiest people, they suggest a plan that could spread happiness to the people who are strong without being wealthy. Vonnegut's revision and critique of the American Constitution features as one of the multiple texts in the novel (53), making Slapstick a masterly piece of fiction-withinfiction.

Wilbur and Eliza are both representatives of a social group nobody wishes to know about. They seek to spread more love around them through a revised constitution and by making their project a leading national concept. They defy the society that oppresses them, and eventually become masters of the territory in which they were rejected, even if Eliza is already dead when the extended family initiative and her other ideas become mainstream.

Eliza's theories are further developed by scientists from China, and lead to the country's prosperity (Slapstick 156). This success refutes the psychologist's diagnosis of Eliza as “feebleminded" (111). The author is challenging the standards of twentieth-century rationality (represented in the psychologist's approach) by showing that centering intelligence on practical skills (like writing) can be pervasive. The different deterritorializations that occur in Wilbur and Eliza's case culminate in an assemblage when they demonstrate new concepts hitherto unknown to people, including their union as one complementary brain in two different bodies, or their cherished idea of the extended artificial family. 
Vonnegut grieves over the fragility of human relations and how easily they are replaced. He calls them "interchangeable parts in the American machine," which refers to the speed with which human beings are forgotten (13). Their absence is not significant as nobody makes the least effort to remember them. The saddest example of humans as interchangeable is that of his uncle, Alex Vonnegut, who attends Alcoholics Anonymous meetings to overcome his loneliness after he has lost every member of his family (7-9). The "American machine" metaphorically stands for the alternatives to family. The prologue reveals that the Vonnegut family members led separate lives, nonetheless they could still identify with other people as family members based on their activities as scientists, or writers, or Americans of German ancestry (5). A family in the "American machine" is not centered on biological relations only: the more "artificial relatives" an individual can have in the American Machine, the more love they can receive.

Vonnegut considers loneliness as the "dominant malaise" of modern American society (Freese 407). Thus, in the prologue, he assigns to himself "artificial extended families" made of people who share the same interests and occupations as he does. He can find brothers everywhere in America, for instance, other writers, while his biological brother Bernard is the brother of all American scientists (5). Although America is a "lonesome society that's been fragmented by the factory system," Vonnegut still believes in the necessity of a "permanent community of relatives" (qtd. in Freese 408).

The two siblings deterritorialize the traditional sense of family because it abandoned them and denied love to them; hence the new stratum that later becomes a nation-wide system. When Wilbur visits his artificial family in Indianapolis, he reports an exceptionally thrilling experience with them, which is far better than that of being a millionaire, senator, pediatrician, or president of the United States. He admits that " $[\mathrm{t}]$ he people there were poor, and had suffered an awful lot of death, and all the public services had broken down . . . but they put on parades 
and feasts for me, and for Carlos Daffodil Villavicencio [his cook accompanying him on the visit], too" (142).

The concept of family and the need for belonging to a group also occurs in Vonnegut's Cat's Cradle (1963). People who are members of the Karass group are usually honest and have a certain sense of humanism (12), like Ambassador Minton and his wife in the novel. In the Granfalloon group, on the other hand, people like H. Lowe Crosby and his wife, Hazel, believe in ridiculous ideologies and think they can give meaning to their lives by them (65). Craving for a family also appears in Galàpagos (1985), finding its expression in the small group that becomes the new human race, while in God Bless You, Mr. Rosewater (1965) this theme is interwoven, in a less direct way, with the protagonist attempting to give love to strangers and those in need. They all share the idea of a minimized community where the members identify with each other and feel they can only find home in each other's company.

By the dispersion of the artificial families in Slapstick's America, a series of displacements and new lines of flight spread around the country and go out of control. Family clubs are set up, family newspapers, and even new sub-families based on the numbers and names are randomly assigned to everyone. The series of estrangements and escapes turn into endless assemblages.

The estrangement of Wilbur and Eliza occurs in two phases in the novel. They are presented first as awful and odd-looking creatures, but it is their astonishing and uncommon appearance that actually spurs them to lead a secret life and later results in their ingenious discoveries, such as the concept of the extended family. Since assemblages have no structure or limitations, their lines of articulation are free to flow endlessly. Eliza's lines of articulation do not stop at Wilbur or the intimate comfort they enjoy together. After their separation, Wilbur does not recall Eliza at all until she appears again for her revenge. Her anger prompts her to sell her theories to the Chinese government and then participate in an experiment in which she dies 
on planet Mars. Estrangement occurs many times in the novel as a fuel for novum and difference. It is through this phenomenon that the novel reaches its status as minor literature.

Estrangement also happens at the level of language itself, in the different reterritorializations of the novel, in which America is no longer the same country. The government collapses due to an economic crisis, and the future America is a composition of small kingdoms of self-governing families instead of states. By the end of the novel new concepts, or assemblages, are born, unknown to the America of Vonnegut's time, with social escape explicit in the form of the artificial families and sub-families that emerge as a consequence.

Another assemblage arising as a consequence of the extended family is that of social equality, which is finally achieved thanks to Wilbur and Eliza's project. Although the country is on its economic knees during Wilbur's term, individuals no longer feel lonely and can find support wherever they go in America. Wilbur at the end admits that he feels more peaceful when surrounded by his simple family than by high officials (142).

\section{Conclusion}

Vonnegut's novel Slapstick, or Lonesome no More! qualifies as minor literature, as conceptualized by Deleuze and Guattari in their notions of deterritorialization, reterritorialization, and assemblages. Several attributes testify to this claim: the novel's selfreflexivity, its artificiality in terms of the author's intrusion in the narration, the psychological complexity of the characters, their incestuous relationship, and the chaotic situation in a future United States, which ceases to be a political power and is merely reduced to a territory of families.

Vonnegut speaks for groups who share the experience of marginalization and a potential sense of loss in a powerful modern America. In Deleuze and Guattari's model, language 
deterritorialization is linked to the impossibility of writing in the language of the oppressor, and the impossibility of not doing so. To clarify this point they refer to Kafka, who could not write in his mother tongue because he was denied the right of belonging to that culture, but it was equally impossible for him not to write at all, or to write in any other language which does not represent him (Deleuze and Guattari, Kafka 16). Although Vonnegut did not have to face the loss of his language as he had never been denied the use of his mother tongue in writing, the impossibilities for him occur in the inability of his culture to represent the true feelings of his generation. Deterritorialization in his case is related to defamiliarizations of common concepts that build the culture he defies. Therefore, he deterritorializes essential concepts such as family, love, and perception, then reterritorializes them in a universe of his making, whereby a certain level of social equality is achieved.

The second aspect of minor literature is politicization in the sense that disturbing issues of a group are foregrounded as opposed to their representations in grand narratives which treat them as insignificant. Wilbur and Eliza could speak for any two Americans that are not physically attractive or powerful and who do not get any attention. Their parents in the novel do what characters in grand narratives do to minorities (send them away and forget about them). The narrative in Slapstick is not about the siblings' beautiful, rich, and well-mannered parents, but about the children's secret life and their ingenuity in their isolation: a scenario extended to other groups in America, to include the miserable lives of the least fortunate after Wilbur becomes president.

The third aspect of minor literature suggests that it is a literature that establishes a style of its own, which makes it different from the literature of the grand narratives of recognized "masters" (Deleuze and Guattari, Kafka 17). Experimentation with the text and its forms becomes a key contributor to its excellence. Vonnegut ingeniously disrupts the traditional plot structure by juxtaposing three different plots, which can be read rhizomatically, and with 
distinct interpretations of each. His immersion in the narration at the end is also another disruption of the autonomy of the text, and it is a technique with which he creates a direct link between the narrated fiction and his life.

University of Tlemcen, Algeria

\section{Works Cited}

Deleuze, Gilles and Félix Guattari. A Thousand Plateaus: Capitalism and Schizophrenia. Trans. Brian Massumi. Minneapolis: U of Minnesota P, 2005. Print.

---. Kafka: Toward a Minor Literature. Trans. Dana Polan. Minneapolis: U of Minnesota P, 2003. Print.

De Landa, Manuel. Assemblage Theory. Edinburgh: Edinburgh UP, 2016. Print.

Freese, Peter. The Clown of Armageddon. Heidelberg: Winter, 2009. Print.

Jenks, Chris. Transgression. London: Routledge, 2003. Print.

Roberts, Adam. The History of Science Fiction. New York: Palgrave, 2006. Print.

Suvin, Darko. Metamorphoses of Science Fiction. London: Yale UP, 1979. Print

Vonnegut, Kurt. Cat's Cradle. London: Penguin, 2011. Print

---. Galápagos. New York: Dial Press. 1985. Print

---. God Bless you, Mr. Rosewater. New York: Delacorte, 1965. Print

--. Slapstick, or Lonesome no More! New York: Dell, 1989. Print

Waugh, Patricia. Metafiction, the Theory and Practice of Self-Conscious Fiction. London: Routledge, 2001. Print. 